\title{
Synthesis of novel 1,3,4-oxadiazole derivatives and their biological properties
}

\author{
ASIF HUSAIN* \\ MOHAMMED AJMAL \\ Department of Pharmaceutical \\ Chemistry, Faculty of Pharmacy \\ Jamia Hamdard (Hamdard University) \\ New Delhi-110062, India
}

\begin{abstract}
A novel series of 2-[3-(4-bromophenyl)propan-3-one]-5-(substituted phenyl)-1,3,4-oxadiazoles (4a-n) have been synthesized from 3-(4-bromobenzoyl)propionic acid (3) with the aim to get better anti-inflammatory and analgesic agents with minimum or without side effects (ulcerogenicity). Compound 3 was reacted with several aryl acid hydrazides (2a-n) in phosphorous oxychloride to obtain the title compounds. Structures of the synthesized compounds were supported by means of IR, ${ }^{1} \mathrm{H}$ NMR and mass spectroscopy. Title compounds were evaluated for their anti-inflammatory, analgesic, ulcerogenic and antibacterial activities. Antibacterial activity was expressed as the corresponding minimum inhibitory concentration (MIC). A fair number of compounds were found to have significant anti-inflammatory and analgesic activities, while a few compounds showed appreciable antibacterial activity. The newly synthesized compounds showed very low ulcerogenic action. The findings of the present study indicate that cyclization of the carboxylic group of 3 into novel 1,3,4-oxadiazole nucleus resulted in increased anti-inflammatory and analgesic activities with a significant decrease of ulcerogenic activity.
\end{abstract}

Keywords: 1,3,4-oxadiazoles, aroylpropionic acid, anti-inflammatory, analgesic activity, antibacterial activity

Heterocyclic compounds containing the five-membered oxadiazole nucleus possess a diversity of useful biological effects. 1,3,4-Oxadiazole and 3-aroylpropionic acid moieties are important because of their versatile biological actions. In particular, compounds bearing the 1,3,4-oxadiazole nucleus are known to have unique antioedema and anti-inflammatory activities (1-3). Differently substituted oxadiazole moieties have also been found to have other interesting activities such as analgesic $(2,3)$, antimicrobial (4), antitubercular (5), anticonvulsant (6) and anti-hepatitis B viral activities (7). Non-steroidal anti-inflammatory drugs NSAIDs form a class of therapeutic agents that are most

\footnotetext{
* Correspondence; e-mail: drasifhusain@yahoo.com
} 
widely used because of their anti-inflammatory, analgesic and antipyretic effects. The prevalent side effects of NSAIDs are the occurrence of gastrointestinal side effects like gastric upset, irritation and ulceration (8). 3-(4-Bromobenzoyl)propionic acid is an example of the well known aroylpropionic acid class of non steroidal anti-inflammatory agents. Aroylpropionic acids are effective anti-inflammatory agents and some of them are commercially available; however, they are associated with gastrointestinal side effects $(9,10)$. Studies suggest that direct tissue contact of these agents plays an important role in the production of side effects (11) and the reported literature confirms that gastrointestinal side effects of aroylpropionic acids are due to the presence of a free carboxylic group in the parent drug (10-12). Thus, developing new agents with minimum or without side effects is an extensive research area at present.

Our studies $(12,13)$ and studies of other researchers $(3)$ have shown that derivatization of the carboxylate function of some NSAIDs resulted in an increased anti-inflammatory activity with a reduced ulcerogenic effect. Hence, it is not irrelevant to speculate that replacing the terminal carboxylic function of 3-(4-bromobenzoyl)propionic acid by oxadiazole ring may enhance the anti-inflammatory activity of such compounds. Therefore, it was considered worthwhile to synthesize some new 3-(4-bromobenzoyl)propionic acid derivatives by incorporating the oxadiazolyl moiety, hoping to get better anti-inflammatory molecules. In view of the reported activities of 1,3,4-oxadiazoles, these compounds were also tested for their analgesic and antibacterial activities.

\section{EXPERIMENTAL}

Chemicals were procured from E. Merck (India) and S. D. Fine Chemicals (India). Melting points were taken in open capillary tubes and are uncorrected. Microanalysis of the compounds was done on a Perkin-Elmer model 240 analyzer (Perkin-Elmer, USA) and the values were found within $\pm 0.4 \%$ of the theoretical values. IR $(\mathrm{KBr})$ spectra were recorded on a Perkin-Elmer 157 infrared spectrometer $\left(v_{\max }\right.$ in $\left.\mathrm{cm}^{-1}\right)$ (Perkin-Elmer, USA) and ${ }^{1} \mathrm{H}$ NMR spectra were recorded on a Varian E-360 MHz (Perkin-Elmer, USA) or Bruker spectrometer DPX-300MHz (Bruker, Germany) with tetramethylsilane (TMS) as an internal standard. Mass spectra were recorded on a Jeol JMS-D 300 instrument (Jeol, Japan) fitted with a JMS 2000 data system at $70 \mathrm{eV}$. Spectral data are consistent with the assigned structures. The progress of the reactions was monitored on silica gel G plates using iodine vapour as visualizing agent. All solvents were distilled prior to use.

\section{Syntheses}

Aryl acid ethyl esters (1a-n) and their hydrazide derivatives (2a-n) were obtained by the method reported in the literature (14).

3-(4-Bromobenzoyl)propionic acid (3). - To a solution of succinic anhydride $(0.1 \mathrm{~mol})$ in bromobenzene $(50 \mathrm{~mL})$, anhydrous aluminium chloride $(0.11 \mathrm{~mol})$ was added in small portions over a period of $2 \mathrm{~h}$ under stirring. The reaction mixture was then refluxed for two hours and after completion of the reaction, excess bromobenzene was removed by steam distillation. It was purified by dissolving in sodium hydroxide solution, filtering, 
followed by addition of hydrochloric acid. The solid so obtained was filtered, washed with cold water, dried and crystallized from methanol to give a cream colored product, which gave effervescence with sodium bicarbonate solution.

2-[3-(4-Bromophenyl)propan-3-one]-5-(substituted phenyl)-1,3,4-oxadiazoles (4a-n). General procedure. - Appropriate aryl acid hydrazide $(2 \mathbf{a}-\mathbf{n})(1 \mathrm{mmol})$ was dissolved in phosphorous oxychloride $(5 \mathrm{~mL})$ and 3-(4-bromobenzoyl)propionic acid (3) $(1 \mathrm{mmol})$ was added. The reaction mixture, after refluxing for $5 \mathrm{~h}$, was cooled to room temperature and poured onto crushed ice. On neutralization of the contents with sodium bicarbonate solution $(20 \%)$, a solid separated out and was filtered, washed with water and dried. It was crystallized from methanol to give 2-[3-(4-bromophenyl)propan-3-one]-(substituted phenyl)-1,3,4-oxadiazoles (4a-n); their physical constants and spectral data are shown in Table I.

\section{Pharmacology}

The animals used in the study were housed in accordance with the Jamia Hamdard Animal Care Unit, which follows the guidelines and rules laid down by the Committee for the Control and Supervision of Experiments on Animals (CPCSEA), Ministry of Social Justice and Empowerment, Goverment of India. The studies were undertaken with prior approval from the Institutional Animal Ethics Committee (IAEC) and utmost care was taken to ensure that the animals were treated in the most humane and acceptable manner. Wistar rats and albino mice of either sex (Hamdard University, Animal House, New Delhi, India), weighing 180-200 g and 22-25 g, respectively, were used. Pregnant females were excluded. The animals were housed in groups of six at room temperature of $25 \pm 2{ }^{\circ} \mathrm{C}$ under $12 \mathrm{~h}$ light/12 h dark cycle with access to food and water ad libitum. Animals were acclimatized to the laboratory for at least 2 days prior to testing.

Anti-inflammatory activity. - This activity was tested according to the method of Winter et al. (15) on Wistar rats. The rats were divided into thirteen groups of six animals each. Freshly prepared aqueous suspension of carrageenean $(1 \% \mathrm{~m} / \mathrm{V}, 0.1 \mathrm{~mL})$ was injected in the planta aponeurosis of the right hind paw of each rat. One group was kept as a control and the animals of other groups were pretreated with test drugs $\left(20 \mathrm{mg} \mathrm{kg}^{-1}\right.$ body mass) given orally 30 minutes before carrageenean injection. The foot volume was measured before and $4 \mathrm{~h}$ after carrageenean injection with a plethysmograph. The mean increase in the paw volume in each group was calculated. Indomethacin and compound 3 were used as standard drugs for comparison.

Analgesic activity. - The compounds that exhibited good anti-inflammatory activity (> $45 \%$ ) were screened for analgesic activity. Analgesic activity was tested by the acetic acid induced writhing method (16). The mice were divided into seven groups of six animals each. A $1 \%$ aqueous acetic acid solution (i.p. injection, $0.1 \mathrm{~mL}$ ) was used as a writhing inducing agent. Mice were kept individually in the test cage before acetic acid injection and habituated for $30 \mathrm{~min}$. Screening of analgesic activity was performed after i.p. administration of test drugs and the reference drug (acetylsalicylic acid) at a dose of 25 $\mathrm{mg} \mathrm{kg}^{-1}$. All the compounds were injected as CMC suspension (1\%). One group was kept as control and received 1\% CMC. After 20 minutes of drug administration, $0.10 \mathrm{~mL}$ of $1 \%$ acetic acid solution was given to mice intraperitoneally. Severity of the writhing 
Table I. Characterization data of the synthesized compounds

\begin{tabular}{|c|c|c|c|c|c|c|c|}
\hline \multirow[b]{2}{*}{$\begin{array}{l}\text { Compd. } \\
\text { No. }\end{array}$} & \multirow[b]{2}{*}{$\mathrm{R}$} & \multirow[b]{2}{*}{$\begin{array}{l}\text { M.p. } \\
\left({ }^{\circ} \mathrm{C}\right)\end{array}$} & \multirow[b]{2}{*}{$\begin{array}{l}\text { Yield } \\
(\%)\end{array}$} & \multirow[b]{2}{*}{$\begin{array}{l}\text { Mol. formula } \\
\text { (molecular } \\
\text { mass) }\end{array}$} & \multicolumn{3}{|c|}{ Spectral data } \\
\hline & & & & & $\begin{array}{l}\mathrm{IR}(\mathrm{KBr}) \\
\left(v, \mathrm{~cm}^{-1}\right)\end{array}$ & $\begin{array}{c}{ }^{1} \mathrm{H} \text { NMR } \\
\left(\mathrm{CDCl}_{3}, \delta, \mathrm{ppm}\right)\end{array}$ & $\begin{array}{l}\text { Mass } \\
\text { spectra } \\
(\mathrm{m} / \mathrm{z})\end{array}$ \\
\hline 3 & - & 108 & 62 & $\begin{array}{c}\mathrm{C}_{10} \mathrm{H}_{9} \mathrm{BrO}_{3} \\
(257.08)\end{array}$ & $\mathrm{nr}$ & $\begin{array}{l}2.53 \text { and } 3.48(\mathrm{t}, \\
\left.\text { each, } 2 \times \mathrm{CH}_{2}\right), 7.52 \\
\text { and } 7.87(\mathrm{~d} \text {, each, } \\
\mathrm{A}_{2} \mathrm{~B}_{2}, p \text {-substituted } \\
\text { phenyl) }\end{array}$ & $\mathrm{nr}$ \\
\hline $4 a$ & & 130 & 61 & $\begin{array}{c}\mathrm{C}_{17} \mathrm{H}_{13} \mathrm{BrN}_{2} \mathrm{O}_{2} \\
(357.20)\end{array}$ & $\begin{array}{l}2938(\mathrm{C}-\mathrm{H}), \\
1731(\mathrm{C}=\mathrm{O}), \\
1652(\mathrm{C}=\mathrm{N})\end{array}$ & $\begin{array}{l}2.56 \text { and } 3.51 \\
\left(\mathrm{t}, \text { each, } 2 x \mathrm{CH}_{2}\right), \\
7.36(\mathrm{~m}, 3 \mathrm{H}, \mathrm{H}-3,4,5, \\
\text { phenyl), } 7.75(\mathrm{~m}, \\
2 \mathrm{H}, \mathrm{H}-2,6, \text { phenyl), } \\
7.66 \text { and } 7.87(\mathrm{~d}, \\
\text { each, } \mathrm{A}_{2} \mathrm{~B}_{2} \\
\text { p-disubstituted } \\
\text { phenyl) }\end{array}$ & $\begin{array}{c}357\left[\mathrm{M}^{+}\right] \\
184,156 \\
91,78,77\end{array}$ \\
\hline $4 b$ & & $120-122$ & 58 & $\begin{array}{c}\mathrm{C}_{17} \mathrm{H}_{12} \mathrm{ClBrN}_{2} \mathrm{O}_{2} \\
(391.65)\end{array}$ & $\begin{array}{l}2955(\mathrm{C}-\mathrm{H}), \\
1729(\mathrm{C}=\mathrm{O}), \\
1654(\mathrm{C}=\mathrm{N})\end{array}$ & $\begin{array}{l}2.57 \text { and } 3.53(\mathrm{t}, \\
\left.\text { each, } 2 \times \mathrm{CH}_{2}\right), 7.32 \\
(\mathrm{~m}, 4 \mathrm{H}, \mathrm{H}-3,4,5,6, \\
o \text {-chloro phenyl), } \\
7.73 \text { and } 7.84(\mathrm{~d}, \\
\text { each, } \mathrm{A}_{2} \mathrm{~B}_{2}, p \text {-disub- } \\
\text { stituted phenyl) }\end{array}$ & $\begin{array}{c}392 \\
{\left[\mathrm{M}^{+}+1\right]} \\
391\left[\mathrm{M}^{+}\right] \\
156,105 \\
77\end{array}$ \\
\hline $4 c$ & & 142 & 62 & $\begin{array}{c}\mathrm{C}_{17} \mathrm{H}_{12} \mathrm{ClBrN}_{2} \mathrm{O}_{2} \\
(391.65)\end{array}$ & $\begin{array}{l}2960(\mathrm{C}-\mathrm{H}), \\
1730(\mathrm{C}=\mathrm{O}), \\
1660(\mathrm{C}=\mathrm{N})\end{array}$ & $\begin{array}{l}2.60 \text { and } 3.55(\mathrm{t}, \\
\left.\text { each, } 2 \times \mathrm{CH}_{2}\right), 7.43 \\
\text { and } 7.68(\mathrm{~d} \text {, each, } \\
\mathrm{A}_{2} \mathrm{~B}_{2}, p \text {-bromophe- } \\
\text { nyl }), 7.65 \text { and } 7.88(\mathrm{~d}, \\
\text { each, } \mathrm{A}_{2} \mathrm{~B}_{2} \text {, } \\
\text {-chlorophenyl) }\end{array}$ & $\begin{array}{c}392 \\
{\left[\mathrm{M}^{+}+1\right]} \\
391\left[\mathrm{M}^{+}\right] \\
156,105 \\
91\end{array}$ \\
\hline $4 d$ & & $136-138$ & 66 & $\begin{array}{c}\mathrm{C}_{17} \mathrm{H}_{13} \mathrm{BrN}_{2} \mathrm{O}_{3} \\
(373.20)\end{array}$ & $\begin{array}{l}2938(\mathrm{C}-\mathrm{H}), \\
1735(\mathrm{C}=\mathrm{O}), \\
1645(\mathrm{C}=\mathrm{N})\end{array}$ & $\begin{array}{l}2.62 \text { and } 3.53(\mathrm{t}, \\
\left.\text { each, } 2 \times \mathrm{CH}_{2}\right), 7.26 \\
(\mathrm{~m}, 4 \mathrm{H}, \mathrm{H}-3,4,5,6, \\
o \text {-disubstituted } \\
\text { phenyl), } 7.71 \text { and } \\
7.85\left(\mathrm{~d}, \text { each, } \mathrm{A}_{2} \mathrm{~B}_{2},\right. \\
\text {-disubstituted } \\
\text { phenyl) }\end{array}$ & $\begin{array}{c}\mathrm{M}^{+} \text {not ob- } \\
\text { served, } \\
184,156\end{array}$ \\
\hline $4 e$ & & 152 & 54 & $\begin{array}{c}\mathrm{C}_{17} \mathrm{H}_{12} \mathrm{BrN}_{3} \mathrm{O}_{4} \\
(402.20)\end{array}$ & $\begin{array}{l}2935(\mathrm{C}-\mathrm{H}), \\
1741(\mathrm{C}=\mathrm{O}), \\
1648(\mathrm{C}=\mathrm{N})\end{array}$ & $\begin{array}{l}2.61 \text { and } 3.56(t, \\
\left.\text { each, } 2 x \mathrm{CH}_{2}\right), 7.77 \\
\text { and } 7.83(\mathrm{~d} \text {, each, } \\
\mathrm{A}_{2} \mathrm{~B}_{2}, p \text {-nitrophenyl), } \\
7.73 \text { and } 7.92(\mathrm{~d}, \\
\text { each, } \mathrm{A}_{2} \mathrm{~B}_{2} \text {, } \\
\text { p-disubstituted } \\
\text { phenyl) }\end{array}$ & $\begin{array}{l}402\left[\mathrm{M}^{+}\right] \\
184,156 \\
77\end{array}$ \\
\hline
\end{tabular}


$4 \mathrm{f}$<smiles>Cc1ccc(F)cc1</smiles>
65

$4 \mathrm{~g}$<smiles>Cc1ccc(I)cc1</smiles>

$4 h$

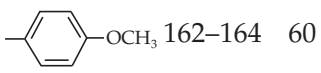

$4 \mathrm{i}$<smiles>COc1ccc(C)cc1OC</smiles>
64<smiles>[SiH3]Cc1ccccc1</smiles>
$154-156 \quad 54$
$\mathrm{C}_{17} \mathrm{H}_{12} \mathrm{BrFN}_{2} \mathrm{O}_{2}$

$2956(\mathrm{C}-\mathrm{H}), 2.58$ and $3.54(\mathrm{t}$,

$1734(\mathrm{C}=\mathrm{O})$, each, $\left.2 \times \mathrm{CH}_{2}\right), 7.65$

$1653(\mathrm{C}=\mathrm{N})$ and $7.98(\mathrm{~d}$, each,

$\mathrm{A}_{2} \mathrm{~B}_{2}, p$-fluoro phenyl), 7.61 and $7.87\left(\mathrm{~d}\right.$, each, $\mathrm{A}_{2} \mathrm{~B}_{2}$, p-disubstituted phenyl)

$\mathrm{C}_{18} \mathrm{H}_{15} \mathrm{BrN}_{2} \mathrm{O}_{2}$ (371.23)

$2940(\mathrm{C}-\mathrm{H}), 2.15$ (s, 3H, $\left.\mathrm{CH}_{3}\right)$, $1741(\mathrm{C}=\mathrm{O}), 2.56$ and $3.51(\mathrm{t}$, $1648(\mathrm{C}=\mathrm{N})$ each, $\left.2 \times \mathrm{CH}_{2}\right), 6.96$ and $7.63(\mathrm{~d}$, each, $\mathrm{A}_{2} \mathrm{~B}_{2}$, p-methylphen$\mathrm{yl}), 7.59$ and $7.85(\mathrm{~d}$, each, $\mathrm{A}_{2} \mathrm{~B}_{2}$, $p$-disubstituted phenyl), 7.46 ( $\mathrm{m}, 5 \mathrm{H}$, phenyl)

$\mathrm{C}_{18} \mathrm{H}_{15} \mathrm{BrN}_{2} \mathrm{O}_{3}$ (387.23)

$2936(\mathrm{C}-\mathrm{H}), 3.84\left(\mathrm{~s}, 3 \mathrm{H}, \mathrm{OCH}_{3}\right)$, $1744(\mathrm{C}=\mathrm{O}), 2.58$ and $3.51(\mathrm{t}$, $1650(\mathrm{C}=\mathrm{N})$ each, $\left.2 \times \mathrm{CH}_{2}\right), 6.99$ and $7.67(d$, each, $\mathrm{A}_{2} \mathrm{~B}_{2}, p$-methoxyphenyl), 7.56 and $7.85\left(\mathrm{~d}\right.$, each, $\mathrm{A}_{2} \mathrm{~B}_{2}$, $p$-disubstituted phenyl)

$64 \quad \mathrm{C}_{19} \mathrm{H}_{17} \mathrm{BrN}_{2} \mathrm{O}_{4}$ (417.25)

$2933(\mathrm{C}-\mathrm{H}), 3.96$ (two closely $1746(\mathrm{C}=\mathrm{O})$, spaced singlets, $6 \mathrm{H}$, $1647(\mathrm{C}=\mathrm{N})$ 2x $\left.\mathrm{OCH}_{3}\right), 2.61$ and $3.54(\mathrm{t}$, each, $2 \mathrm{x}$ $\left.\mathrm{CH}_{2}\right), 6.99(\mathrm{~d}, 1 \mathrm{H}$, H-5, dimethoxy phenyl), $7.15(\mathrm{~d}, 1 \mathrm{H}$, $\mathrm{H}-2$, dimethoxy phenyl), 7.39 (dd, 1H, H-6, dimethoxy phenyl), 7.71 and $7.97\left(d\right.$, each, $\mathrm{A}_{2} \mathrm{~B}_{2}$, p-disubstituted phenyl)
$\mathrm{C}_{18} \mathrm{H}_{15} \mathrm{BrN}_{2} \mathrm{O}_{2}$ (371.23)

$$
\text { phenyl) }
$$

$2942(\mathrm{C}-\mathrm{H}), 2.56$ and $3.53(\mathrm{t}$, $1739(\mathrm{C}=\mathrm{O})$, each, $\left.2 \mathrm{x} \mathrm{CH}_{2}\right), 4.12$
376

$\left[\mathrm{M}^{+}+1\right]$, $375\left[\mathrm{M}^{+}\right]$, 156, 105, 77

$371\left[\mathrm{M}^{+}\right]$,

184, 156,

91,77

$387\left[\mathrm{M}^{+}\right]$

156, 105

$417\left[\mathrm{M}^{+}\right]$,

184, 156,

78,77

$1645(\mathrm{C}=\mathrm{N}) \quad\left(\mathrm{s}, 2 \mathrm{H}, \mathrm{CH}_{2}\right), 7.42$

$371\left[\mathrm{M}^{+}\right]$, (m, 3H, H-3,4,5, phenyl), 7.63 (m, 2H, H-2,6, phenyl), 7.66 and $7.84(\mathrm{~d}$, each, $\mathrm{A}_{2} \mathrm{~B}_{2}, p$-disubstituted phenyl) 
$4 k$<smiles>CCOc1ccccc1</smiles>
$162-164 \quad 62$

41<smiles>Cc1ccccc1C(=O)c1ccccc1</smiles>
$122-124 \quad 57$ $4 \mathrm{~m}$<smiles>CCOc1cccc2ccccc12</smiles>
61 $4 n$

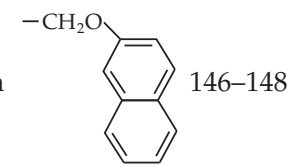
$\mathrm{C}_{18} \mathrm{H}_{15} \mathrm{BrN}_{2} \mathrm{O}_{3}$
$(387.23)$

$2936(\mathrm{C}-\mathrm{H}), 2.58$ and $3.55(\mathrm{t}$, $1737(\mathrm{C}=\mathrm{O})$, each, 2x $\left.\mathrm{CH}_{2}\right), 4.56$ $1652(\mathrm{C}=\mathrm{N}) \quad\left(\mathrm{s}, 2 \mathrm{H}, \mathrm{OCH}_{2}\right), 7.48$ (m, 3H, H-3,4,5, phenyl), $7.63(\mathrm{~m}$, $2 \mathrm{H}, \mathrm{H}-2,6$, phenyl), 7.71 and $7.86(\mathrm{~d}$, each, $\mathrm{A}_{2} \mathrm{~B}_{2}$, p-disubstituted phenyl)

$\mathrm{C}_{24} \mathrm{H}_{17} \mathrm{BrN}_{2} \mathrm{O}_{3}$
$(461.31)$

$2950(\mathrm{C}-\mathrm{H}), 2.53$ and $3.51(\mathrm{t}$,

$1746(\mathrm{C}=\mathrm{O})$, each, $\left.2 \times \mathrm{CH}_{2}\right)$,

$1644(\mathrm{C}=\mathrm{N})$ 7.23-7.66 (m, 9H, o-benzoylphenyl), 7.68 and $7.85(\mathrm{~d}$, each, $\mathrm{A}_{2} \mathrm{~B}_{2}, p$-disubstituted phenyl)

$\mathrm{C}_{22} \mathrm{H}_{17} \mathrm{BrN}_{2} \mathrm{O}_{3}$ (437.29)

29 $(\mathrm{C}-\mathrm{H}), 2.57$ and $3.56(\mathrm{t}$, $(\mathrm{C}=\mathrm{O})$, each, $\left.2 \mathrm{x} \mathrm{CH}_{2}\right), 2.82$ $1652(\mathrm{C}=\mathrm{N}) \quad\left(\mathrm{s}, 2 \mathrm{H}, \mathrm{CH}_{2}\right), 7.36 \&$ 7.79 (m, each, $7 \mathrm{H}$, naphthyl), 7.65 and $7.87\left(\mathrm{~d}\right.$, each, $\mathrm{A}_{2} \mathrm{~B}_{2}$, $p$-disubstituted phenyl)

$\mathrm{C}_{22} \mathrm{H}_{17} \mathrm{BrN}_{2} \mathrm{O}_{3}$ (437.29)
$3 \quad 2945$ $1732(\mathrm{C}=\mathrm{O})$,
$1651(\mathrm{C}=\mathrm{N})$

$$
\begin{array}{ll} 
& \text { phenyl) } \\
2945(\mathrm{C}-\mathrm{H}), & 2.56 \text { and } 3.53(\mathrm{t}, \text { each }
\end{array}
$$

, 2.56 and $3.53\left(t\right.$, each, $437\left[\mathrm{M}^{+}\right]$ $\left.\mathrm{CH}_{2}\right), 2.89(\mathrm{~s}, 2 \mathrm{H}, \quad 184,127$ , $7.28 \& 7.83$ $(\mathrm{m}$, each, $7 \mathrm{H}$, naphthyl), 7.71 and 7.86 (d, each, $\mathrm{A}_{2} \mathrm{~B}_{2}, p$-disubstituted phenyl)
$387\left[\mathrm{M}^{+}\right]$,

184,106 ,

105,77

$448\left[\mathrm{M}^{+}\right.$, not observed], 196,184, 156,77

$437\left[\mathrm{M}^{+}\right]$ 184,157 , 127

$\mathrm{s}$ - singlet, $\mathrm{d}$ - doublet, $\mathrm{t}$ - triplet, $\mathrm{q}$ - quartet, $\mathrm{m}$ - multiplet, $\mathrm{nr}$ - not recorded

response was recorded for $20 \mathrm{~min}$ after administration of acetic acid solution. The analgesic activity was expressed in terms of \% protection.

Ulcerogenic activity. - Acute ulcerogenesis test was performed according to the method of Cioli et al. (11). The rats were divided into eight groups of six animals each. Ulcerogenic activity was evaluated after p.o. administration of test compounds or indomethacin or compound 3 at a dose of $60 \mathrm{mg} \mathrm{kg}^{-1}$ body mass. Control group of rats received the vehicle (suspension of $1 \%$ CMC). Food, but not water, was removed $24 \mathrm{~h}$ before administration of the test compounds. After the drug treatment, the rats were fed normal diet for $17 \mathrm{~h}$ and were then sacrificed. The stomach was removed and opened along the greater curvature, washed with distilled water and cleaned gently by dipping in saline. The gastric mucosa of the rats was examined using a magnifying glass. For each stomach, the mucosal damage was assessed according to the following system: 0.5 - redness, $1.0-$ spot ulcers, 1.5 - hemorrhagic streaks, $2.0-3 \leq$ ulcers $\leq 5,3.0$ - ulcers $>5$. The mean score of each treated group was regarded as the severity index of gastric mucosal damage. 
Antibacterial activity. - Gram positive (Staphylococcus aureus), and Gram negative (Escherichia coli) bacterial strains were used. The test was carried out in meat peptone agar medium at a concentration of $100 \mu \mathrm{g} \mathrm{mL}^{-1}$ by the cup plate method (17). A series of dilutions was prepared in dimethylformamide (DMF) with sterile pipettes. To each of the series of sterile stopper test tubes, a standard volume of nutrient broth medium was added. A control tube, containing no antimicrobial agent was included. The inoculum consisting of an overnight broth culture of microorganisms was added to separate tubes. The tubes were incubated at $37{ }^{\circ} \mathrm{C}$ for 24 hours and examined for turbidity. The tubes with the highest dilution showing no turbidity indicated MIC. Nitrofurazone was used as standard drug for comparison.

Statistical analysis. - Data obtained from animal experiments were expressed as mean \pm SEM. Statistical differences between the treatments and the standard were tested by one-way ANOVA followed by Dunnett's multiple comparison test.

\section{RESULTS AND DISCUSSION}

The compounds of interest 4a-n were obtained using 3-(4-bromobenzoyl)propionic acid $\mathbf{3}$ as starting material in the reaction with different aryl acid hydrazides 2a-n in phosphorous oxychloride (reaction time varied from 3 to $5 \mathrm{~h}$ ). The parent compound 3 was prepared by condensing bromobenzene with succinic anhydride in the presence of anhydrous aluminium chloride following Friedel-Craft's acylation reaction conditions. The required aryl acid hydrazides (2a-n) were prepared by esterification of the corresponding aryl acids, followed by treatment with hydrazine hydrate in absolute ethanol (14). The reaction sequence is given in Scheme 1.

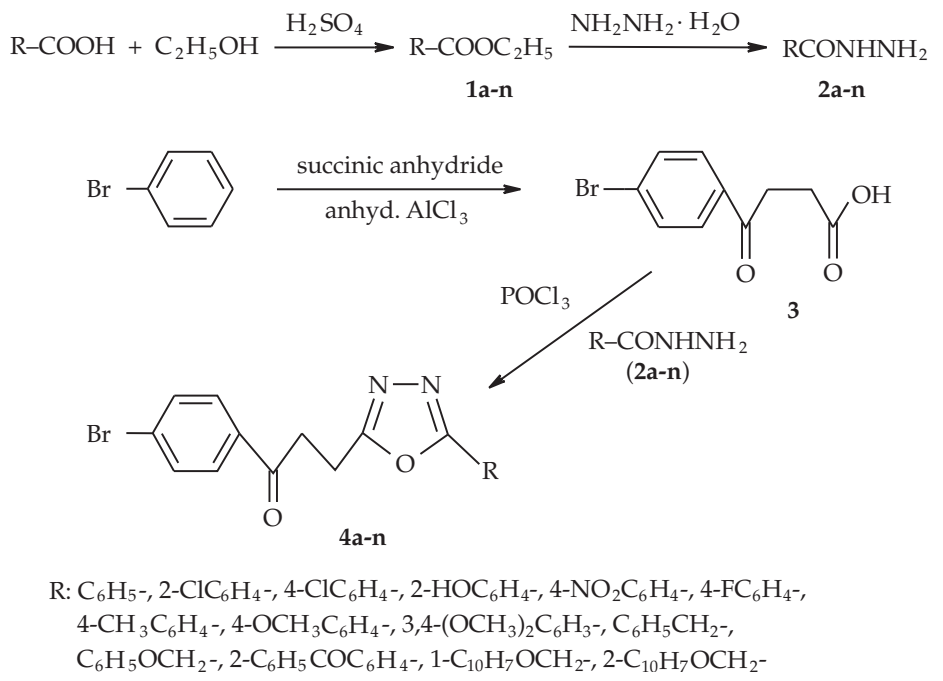

Scheme 1 
Analytical and spectral data $\left({ }^{1} \mathrm{H}\right.$ NMR, IR, mass spectra) of all synthesized compounds were in full agreement with the proposed structures (Table I). In general, infrared spectral data $\left(v, \mathrm{~cm}^{-1}\right)$ revealed bands at 2960-2933 $(\mathrm{C}-\mathrm{H}), 1746-1725(\mathrm{C}=\mathrm{O})$ and $1660-1645$ $(\mathrm{C}=\mathrm{N})$. In the nuclear magnetic resonance spectra $\left({ }^{1} \mathrm{H} \mathrm{NMR}, \delta \mathrm{ppm}\right)$, the signals of the respective protons of the compounds were verified on the basis of their chemical shifts. The spectra showed two triplets at around $\delta 2.47$ and $3.53\left(-\mathrm{CH}_{2}-\mathrm{CH}_{2}-\right)$, a doublet each at around $\delta 7.66$ and $7.91\left(2 \times 2 \mathrm{H}, \mathrm{A}_{2} \mathrm{~B}_{2}, p\right.$-disubstituted phenyl), signals in the region 6.96-8.09 (aryl ring protons). Other signals were observed at appropriate places. The mass spectra showed acylium fragments containing substituted phenyl and aryl moieties as major peaks, followed by peaks with loss of $\mathrm{CO}$ besides the molecular ion peaks with reasonable intensities supporting the structure. In the case of aryl group having chlorine as a substituent, the molecular ion or other related ions produced the appropriate isotopic abundances. Physical constants and spectral data of the title compounds are shown in Table I.

Compounds 4a-n were evaluated for their in vivo anti-inflammatory activity by the carrageenean induced rat paw edema method. The compounds were evaluated at an oral dose of $20 \mathrm{mg} \mathrm{kg}^{-1}$ and compared with the standard drug indomethacin and the parent compound 3 at the same oral dose. The tested compounds showed anti-inflammatory activity ranging from 33.3 to $61.9 \%$ (Table II). Two compounds, 2-[3-(4-bromophenyl)-

Table II. Biological activity of the synthesized compounds

\begin{tabular}{|c|c|c|c|c|c|}
\hline \multirow[t]{2}{*}{ Compd. No. } & \multirow{2}{*}{$\begin{array}{c}\text { Anti-inflammatory } \\
\text { activity } \\
\text { (inhibition, \%) }^{\mathrm{a}}\end{array}$} & \multirow{2}{*}{$\begin{array}{c}\text { Analgesic } \\
\text { activity } \\
\left(\text { protection, \%) }^{\mathrm{a}}\right.\end{array}$} & \multirow{2}{*}{$\begin{array}{c}\text { Ulcerogenic } \\
\text { activity } \\
\text { (severity index) }^{\mathrm{a}}\end{array}$} & \multicolumn{2}{|c|}{$\begin{array}{c}\text { MIC } \\
\left(\mu \mathrm{g} \mathrm{mL}^{-1}\right)\end{array}$} \\
\hline & & & & S. aureus & E. coli \\
\hline $4 a$ & $40.5 \pm 5.32^{\mathrm{b}}$ & & & - & - \\
\hline $4 b$ & $52.4 \pm 3.94$ & $56.6 \pm 1.77$ & $0.83 \pm 0.16^{\mathrm{b}}$ & $>100$ & 50.0 \\
\hline $4 c$ & $59.5 \pm 3.79$ & $66.2 \pm 1.86$ & $0.75 \pm 0.11^{b}$ & 25.0 & 50.0 \\
\hline $4 e$ & $45.6 \pm 4.89^{c}$ & $44.1 \pm 1.86^{\mathrm{b}}$ & $0.58 \pm 0.08^{b}$ & - & $>100$ \\
\hline $4 \mathrm{f}$ & $47.6 \pm 3.01$ & $53.6 \pm 1.88^{b}$ & $0.67 \pm 0.11^{b}$ & 12.5 & 25.0 \\
\hline $4 g$ & $33.3 \pm 5.14^{\mathrm{b}}$ & & & - & - \\
\hline $4 i$ & $61.9 \pm 5.10$ & $70.6 \pm 1.86^{c}$ & $0.83 \pm 0.11^{b}$ & - & - \\
\hline $4 k$ & $54.8 \pm 3.88$ & & & $>100$ & \\
\hline 41 & $35.7 \pm 3.36^{\mathrm{b}}$ & & & - & - \\
\hline $4 m$ & $42.9 \pm 3.47^{c}$ & & & $>100$ & - \\
\hline 3 & $38.1 \pm 5.39^{b}$ & & $1.17 \pm 0.11^{\mathrm{b}}$ & - & - \\
\hline Control & 0 & 0 & 0 & & \\
\hline Indomethacin & $64.3 \pm 5.57$ & & $2.67 \pm 0.21$ & & \\
\hline
\end{tabular}

Acetylsalicylic acid

$63.2 \pm 1.47$

Nitrofurazone

Doses: 20, 25 and $60 \mathrm{mg} \mathrm{kg}^{-1}$ for anti-inflammatory, analgesic and ulcerogenic activity, respectively.

a Mean \pm SEM, $n=6$.

b Significant difference relative to the respective standard: ${ }^{b} p<0.01 ;{ }^{c} p<0.05$. 
propan-3-one]-5-(4-chlorophenyl)-1,3,4-oxadiazole (4c) and 2-[3-(4-bromophenyl)propan-3-one]-5-(3,4-dimethoxy phenyl)-1,3,4-oxadiazole (4i) with anti-inflammatory activity of 59.5 and $61.9 \%$, respectively, were found to have comparable activity with that of indomethacin which showed $64.3 \%$ activity at the same dose of $20 \mathrm{mg} \mathrm{kg}^{-1}$. Eight out of the ten tested compounds have shown better activity than that of the parent aroylpropionic acid 3, which exhibited $38.1 \%$ activity. These data show that the presence of 3,4-dimethoxyphenyl or 4-chlorophenyl or substitution at the $5^{\text {th }}$ position of oxadiazole ring causes remarkable improvement in anti-inflammatory activity. To acquire more information about the quantitative structure-activity relationship (QSAR), further studies are in progress in our laboratory.

The compounds that showed anti-inflammatory activity higher than $45 \%$ were tested for analgesic activity. Compounds $\mathbf{4 b}, \mathbf{4} \mathbf{c}, \mathbf{4 e}, \mathbf{4 f}$, and $\mathbf{4} \mathbf{i}$ showed analgesic activity ranging from 44.1 to $70.6 \%$, whereas the standard drug acetylsalicylic acid showed $63.2 \%$, all at a $25 \mathrm{mg} \mathrm{kg}^{-1}$ i.p. dose (Table II). Among the tested compounds, two compounds, viz. 2-[3-(4-bromophenyl)propan-3-one]-5-(4-chlorophenyl)-1,3,4-oxadiazole (4c) and 2-[3(4-bromophenyl)propan-3-one]-5-(3,4-dimethoxy phenyl)-1,3,4-oxadiazole (4i) with analgesic activity of 66.2 and $70.6 \%$, respectively, were found to have better activity than that of standard drug. Analysis of the results showed that the compounds having 3,4-dimethoxyphenyl or 4-chlorophenyl substitution at the $5^{\text {th }}$ position of oxadiazole ring exhibited significant analgesic activity.

The compounds that were screened for analgesic activity were further tested for their ulcerogenic activity. The ulcerogenic liability of $4 b, 4 c, 4 e, 4 f, 4 i, 3$ and indomethacin was evaluated after oral administration at a dose of $60 \mathrm{mg} \mathrm{kg}^{-1}$ body mass. The tested compounds showed low ulcerogenic activity, ranging from 0.58 to 0.83 . The parent aroyl propionic acid 3 and the standard drug indomethacin showed a high severity index of 1.17 and 2.67, respectively (Table II). The results indicate that cyclized derivatives are almost devoid of ulcerogenic action.

In view of the reported antibacterial activity of oxadiazoles, these compounds were also tested for their antibacterial activity against some selected microbes. The studies were carried out on the synthesized compounds against Staphylococcus aureus and Escherichia coli. Compounds inhibiting growth of one or both microorganisms were further tested for their minimum inhibitory concentration (MIC). Compound 4f, 2-[3-(4-bromophenyl)propan-3-one]-5-(4-fluorophenyl)-1,3,4-oxadiazole showed very good activity against $S$. aureus $\left(M I C=12.5 \mu \mathrm{g} \mathrm{mL}^{-1}\right)$ and good activity against $E$. coli $\left(\right.$ MIC $\left.=25 \mu \mathrm{g} \mathrm{mL}^{-1}\right)$, whereas 2-[3-(4-bromophenyl)propan-3-one]-5-(4-chlorophenyl)-1,3,4-oxadiazole (4c) also showed good activity against $S$. aureus $\left(M I C=25 \mu \mathrm{g} \mathrm{mL}^{-1}\right)$. Thr reference drug, nitrofurazone, showed MIC of $12.5 \mu \mathrm{g} \mathrm{mL}^{-1}$ against $S$. aureus and $6.5 \mu \mathrm{g} \mathrm{mL}^{-1}$ against E. coli. None of the compounds showed activity equivalent to that of the standard drug nitrofurazone except compound $\mathbf{4 f}$, which showed at par activity to that of the standard against S. aureus with MIC of $12.5 \mu \mathrm{g} \mathrm{mL}^{-1}$. 


\section{CONCLUSIONS}

A new class of oxadiazoles was synthesized by cyclization of the terminal carboxylic group of an aroyl propionic acid with the objective to develop better anti-inflammatory and analgesic molecules with or without ulcerogenic activity. The results of biological tests make novel oxadiazoles interesting lead molecules for further synthetic and biological evaluation. It can be concluded that this class of compounds certainly hold great promise for discovering safer anti-inflammatory agents.

Acknowledgements. - The financial support provided by the A.I.C.T.E., New Delhi, under the RPS-scheme, is gratefully acknowledged. The authors are also thankful to Mrs. Shaukat Shah, in charge of the animal house, for providing animals for pharmacological studies and Prof. P. K. Pillai, Head, Microbiology, Majeedia Hospital, India, for helping in carrying out antibacterial tests.

\section{REFERENCES}

1. F. A. Omar, N. M. Mahfouz and M. A. Rahman, Design, synthesis and anti-inflammatory activity of some 1,3,4-oxadiazole derivatives, Eur. J. Med. Chem. 31 (1996) 819-825; DOI: 10.1016/0223$-5234(96) 83976-6$.

2. B. Narayana, K. K. Vijayaraj, B. V. Ashlatha and N. S. Kumari, Synthesis of some new 2-(6-methoxy-2-naphthyl)-5-aryl-1,3,4-oxadiazoles as possible non-steroidal anti-inflammatory and analgesic agents, Arch. Pharm. (Weinheim) 338 (2005) 373-377; DOI: 10.1002/ardp.200400964.

3. M. Amir and S. Kumar, Synthesis and evaluation of anti-inflammatory, analgesic and lipid peroxidation properties of ibuprofen derivatives, Acta Pharm. 57 (2007) 31-45; DOI: 10.2478/v10007-007-0003-y.

4. S. L. Gaonkar, K. M. Rai and B. Prabhuswamy, Synthesis and antimicrobial studies of a new series of 2-\{4-[2-(5-ethylpyridin-2-yl)ethoxy] phenyl\}-5-substituted-1,3,4-oxadiazoles, Eur. J. Med. Chem. 41 (2006) 841-846; DOI: 10.1002/chin.200651110.

5. M. A. Ali and M. S. Yar, Oxadiazole Mannich bases: Synthesis and antimycobacterial activity, Bioorg. Med. Chem. Lett. 17 (2007) 3314-3316; DOI: 10.1016/j.bmcl.2007.04.004.

6. A. Zarghi, S. A. Tabatabai, M. Faizi, A. Ahadian, P. Navabi, V. Zanganeh and A. Shafiee, Synthesis and anticonvulsant activity of new 2-substituted-5-(2-benzyloxyphenyl)-1,3,4-oxadiazole, Bioorg. Med. Chem. Lett. 15 (2005) 1863-1865; DOI: 10.1016/j.bmcl.2005.02.014.

7. T. M. Tan, Y. Chen, K. H. Kong, J. Bai, Y. Li, S. G. Lim, T. H. Ang and Y. Lam, Synthesis and the biological evaluation of 2-benzenesulfonylalkyl-5-substituted-sulfanyl-(1,3,4)-oxadiazoles as potential anti-hepatitis B virus agents, Antiviral Res. 71 (2006) 7-14; DOI: 10.1016/j.antiviral.2006. 02.007 .

8. F. L. Lanza, A guideline for the treatment and prevention of NSAID-induced ulcers, Am. J. Gastroenterol. 93 (1998) 2037-2046; DOI: 10.1016/S0002-9270(98)00469-9.

9. F. Buttgereit, G. Burmester and L. S. Simon, Gastrointestestinal toxic side effects of non-steroidal anti-inflammatory drugs and cyclooxygenase-2-specific inhibitors, Am. J. Med. 110 (2001) 135-195; DOI: $10.10116 /$ S0002-9343(00)00728-2.

10. K. A. Metwally, S. H. Yaseen, E. M. Lashine, H. M. El-Fayomi and M. E. El-Sadek, Non-carboxylic analogues of aroylpropionic acids: Synthesis, anti-inflammatory activity and ulcerogenic potential, Eur. J. Med. Chem. 42 (2007) 152-160. 
11. V. Cioli, S. Putzolu, V. Rossi, P. S. Barcellona and C. Corradino, The role of direct tissue contact in the production of gastrointestinal ulcers by anti-inflammatory drugs in rats, Toxicol. Appl. Pharmacol. 50 (1979) 283-289; DOI: 10.1016/0041-008X(79)90153-4.

12. A. Husain, M. S. Y. Khan, S. M. Hasan and M. M. Alam, 2-Arylidene-4-(4-phenoxy-phenyl)but-3-en-4-olides: Synthesis, reactions and biological activity, Eur. J. Med. Chem. 40 (2005) 1394-1404; DOI: 10.1002/chin.200617109.

13. M. S. Y. Khan and A. Husain, Syntheses and reactions of some new 2-arylidene-4-(biphenyl-4-yl)but-3-en-4-olides with a study of their biological activity, Pharmazie 57 (2002) 448-452.

14. N. Siddiqui, M. S. Alam and W. Ahsan, Synthesis, anticonvulsant and toxicity evaluation of 2-( $1 \mathrm{H}-$ -indol-3-yl)acetyl- $N$-(substituted phenyl)hydrazine carbothioamides and their related heterocyclic derivatives, Acta Pharm. 58 (2008) 445-454; DOI: 10.2478/v10007-008-0025-0.

15. C. A. Winter, E. A. Risley and G. W. Nuss, Carrageenin-induced edema in hind paw of the rat as an assay for anti-inflammatory drugs, Proc. Soc. Exp. Biol. 111 (1962) 544-547.

16. H. O. Collier, L. C. Dinneen, C. A. Johnson and C. Schneider, The abdominal constriction response and its suppression by analgesic drugs in the mouse, Br. J. Pharmacol. 32 (1968) 295-310.

17. R. Cruickshank, J. P. Dugid, D. P. Marmion and R. H. A. Swain, Medical Microbiology, Vol. 2, Churchill, London 1975.

\section{$S A \check{Z} E T A K$}

\section{Sinteza i djelovanje novih derivata 1,3,4-oksadiazola}

ASIF HUSAIN i MOHAMMED AJMAL

Reakcijom 3-(4-brombenzoil)propionske kiseline (3) i aril hidrazida (2a-n) u prisutnosti fosforovog oksiklorida, sintetizirana je serija novih derivata 2-[3-(4-bromfenil)propan-3-on]-5-(supstituiranih fenil)-1,3,4-oksadiazola (4a-n) s ciljem da se dobiju spojevi s boljim protuupalnim i analgetskim, a manjim elcerogenim djelovanjem. Struktura sintetiziranih spojeva potvrđena je IR, ${ }^{1} \mathrm{H}$ NMR i masenom spektroskopijom. Ispitano je protuupalno, analgetsko, ulcerogeno i antibakterijsko djelovanje spojeva 4a-n. Antibakterijsko djelovanje izraženo je kao minimalna inhibitorna koncentracija (MIC). Nekoliko spojeva imalo je značajno protuupalno i analgetsko djelovanje, nekoliko prilično antibakterijsko djelovanje, a svi su imali vrlo slabo ulcerogeno djelovanje. Rezultati ukazuju da ciklizacija karboksilne skupine u spoju 3 u 1,3,4-oksadiazol dovodi do povećanja protuupalnog i analgetskog, a do smanjenja ulcerogenog djelovanja.

Ključne riječi: 1,3,4-oksadiazoli, aroilpropionska kiselina, protuupalno djelovanje, analgetsko djelovanje, antibakterijsko djelovanje

Department of Pharmaceutical Chemistry, Faculty of Pharmacy, Jamia Hamdard (Hamdard University), New Delhi-110062, India 